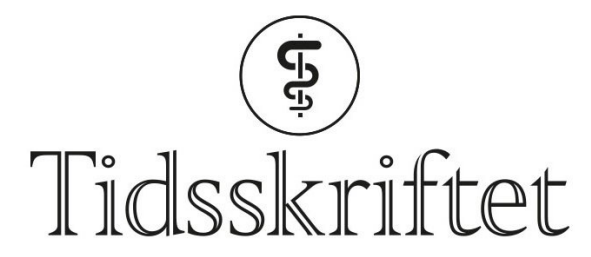

DEN NORSKE LEGEFORENING

\title{
Trådløs overvåking av premature
}

FRA ANDRE TIDSSKRIFTER

HAAKON B. BENESTAD

Universitetet i Oslo

Et ny trådløs registreringsteknologi for overvåking av premature er nå lansert.

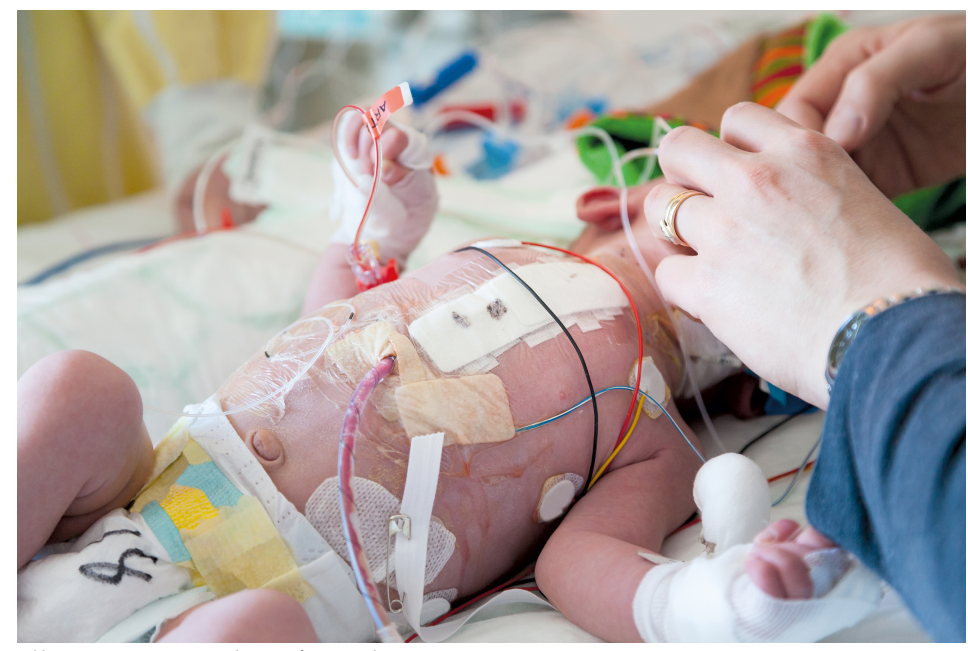

Illustrasjon: perboge/iStock

Standardmetodene i pediatriske overvåkingsenheter anvender elektriske ledninger og intravaskulære kateter, som gir økt risiko for hudinfeksjon og systemiske infeksjoner. Overvåkingen gjør stellet vrient og hindrer hud-til-hud-kontakt mellom nyfødt og mor.

Et ny, trådløs registreringsteknologi for overvåking av premature og spedbarn er nå lansert (1). Den gir signal om vitale tegn med rekkevidde på inntil 1o meter, og sender det til f.eks. et nettbrett. Dessuten registreres andre holdepunkter for hvordan pasienten har det, slik som kroppsbevegelser, kroppsorientering, gråt, stemmebruk og fysiologiske virkninger av oppførsel og hud-til-hud-kontakt. Dette skjer gjennom monitorering og analyse av hudtemperatur, EKG, seismokardiografi, lydopptak, akselerometri og oksygenmetning av kapillærblod.

Monitoreringen gjøres av sensorer i elastiske silikonputer festet til huden med en hydrogel, og energitilførsel kommer fra ladbare batterier eller radiosender under sengen. I pilotstudien med 50 pasienter ble opplegget validert ved sammenlikning med et standardoppsett.

- Det er en stor fordel at premature og andre små pasienter kan overvåkes fysiologisk uten bruk av invasive kateter og elektrodeledninger, sier Marianne Thoresen, som er professor i fysiologi ved Institutt for medisinske basalfag, Universitetet i Oslo, og professor i 
nyfødtmedisin ved St. Michael's Hospital i Bristol.

Hun understreker at de minste intensivpasientene trenger presis og kontinuerlig måling av blodtrykk, hjertefrekvens og blodets oksygeninnhold, men at den nye metoden viser stor variabilitet i måling av blodtrykk og oksygeninnhold. For nyfødte intensivpasienter er marginene for små, men metoden er optimal for å undersøke normalfysiologiske sammenhenger hos barn og voksne. Metoden vil imidlertid sikkert bli videreutviklet, og Thoresen håper at den også vil omfatte EEG-overvåking av hjernen.

\section{LITTERATUR:}

1. Chung HU, Rwei AY, Hourlier-Fargette A et al. Skin-interfaced biosensors for advanced wireless physiological monitoring in neonatal and pediatric intensive-care units. Nat Med 2020; 26: 418-29. [PubMed][CrossRef]

Publisert: 5. juni 2020. Tidsskr Nor Legeforen. DOI: 10.4045/tidsskr.20.0300

(C) Tidsskrift for Den norske legeforening 2020. Lastet ned fra tidsskriftet.no 